\title{
JOYCE: Jülich Observatory for cloud evolution
}

Article

Published Version

Löhnert, U., Schween, J. H., Acquistapace, C., Ebell, K., Maahn, M., Barrera-Verdejo, M., Hirsikko, A., Bohn, B., Knaps, A., O'Connor, E.J., Simmer, C., Wahner, A. and Crewell, S. (2015) JOYCE: Jülich Observatory for cloud evolution. Bulletin of the American Meteorological Society, 96 (7). pp. 1157-1174. ISSN 1520-0477 doi: https://doi.org/10.1175/BAMS-D-1400105.1 Available at https://centaur.reading.ac.uk/42826/

It is advisable to refer to the publisher's version if you intend to cite from the work. See Guidance on citing.

To link to this article DOI: http://dx.doi.org/10.1175/BAMS-D-14-00105.1

Publisher: American Meteorological Society

All outputs in CentAUR are protected by Intellectual Property Rights law, including copyright law. Copyright and IPR is retained by the creators or other copyright holders. Terms and conditions for use of this material are defined in the End User Agreement.

\section{www.reading.ac.uk/centaur}

\section{CentAUR}


Central Archive at the University of Reading

Reading's research outputs online 


\title{
JOYCE Jülich Observatory for Cloud Evolution
}

\author{
by U. Löhnert, J. H. Schween, C. Acquistapace, K. Ebell, M. Maahn, M. Barrera-Verdejo,
} A. Hirsikko, B. Bohn, A. Knaps, E. O'Connor, C. Simmer, A. Wahner, and S. Crewell

\author{
A state-of-the-art array of scanning remote sensing and in situ instruments aims to provide \\ insight into the transition of water vapor to clouds and clouds to precipitation under the \\ influence of different forcing conditions.
}

\begin{abstract}
Understanding when, where, and why clouds begin to form, precipitate, and dissipate is essential for improving their representation in both climate and numerical weather prediction models (Zhang et al. 2005; Walser et al. 2004). Specifically, a deeper insight in boundary layer cloud evolution is necessary for quantifying the effects of these clouds on climate through their coupling to large-scale circulation (Stevens and Bony 2013) and their interaction with solar and terrestrial
\end{abstract}

AfFiliations: Löhnert, SchWeen, Acquistapace, Ebell, MaAhn, Barrera-Verdejo, and Crewell-Institute for Geophysics am Meteorology, University of Cologne, Cologne, Germany; HIRSIKKO, BOHN, AND WAHNER - Institut für Energie- und Klimaforschung: Troposphäre (IEK-8), Forschungszentrum Jülich $\mathrm{GmbH}$, Jülich, Germany; KNAPS-Geschäftsbereich Sicherheit und Strahlenschutz (S-UM), Forschungszentrum Jülich $\mathrm{GmbH}$, Jülich, Germany; O'CONNOR-Department of Meteorology, University of Reading, Reading, United Kingdom, and Finnish Meteorological Institute, Helsinki, Finland; SIMMER — Meteorological Institute, University of Bonn, Bonn, Germany

CORRESPONDING AUTHOR: Dr. Ulrich Löhnert, Institute for Geophysics and Meteorology, Pohligstraße 3, 50969 Köln, Germany

E-mail: loehnert@meteo.uni-koeln.de

The abstract for this article can be found in this issue, following the table of contents.

DOI:I0.II75/BAMS-D-I4-00105.I

In final form 2 October 2014

(C)2015 American Meteorological Society radiation (Turner et al. 2007; Lohmann and Feichter 2005) as well as for improving precipitation prediction (Khairoutdinov and Randall 2006; Wood et al. 2009). Boundary layer cloud development depends on many factors including dynamics (i.e., large-scale forcing and/or turbulence), thermodynamics (water vapor, temperature, phase transition), and aerosols as well as interactions (see "Focus on atmosphere-surface exchange" for more information) with vegetation and surface (Wood 2012; Jiang and Feingold 2006; Betts 2007; Lohou and Patton 2014).

The Jülich Observatory for Cloud Evolution (JOYCE; www.geomet.uni-koeln.de/joyce) has been recently established in order to provide a better physical understanding of these processes. JOYCE aims to characterize the micro- and macrophysical processes of boundary layer clouds as a result of the environments in which they form and in which they decay. To achieve these goals, JOYCE is equipped with a unique array of state-of-the-art remote sensing and in situ instruments, installed at Forschungszentrum Jülich (FZJ). FZJ is located in the most western part of Germany (50 54'31"N, 6²4'49"E, 111 m MSL; Fig. 1), which is, according to the Köppen-Geiger climate classification (Kottek et al. 2006), characterized by a warm temperate, fully humid climate with warm summers. More specifically, the $50-\mathrm{km}$ periphery is characterized by farming, open-cast coal mining areas with major power plants and patchy settlements. Except for a forested 200-m-high mine pile 


\section{FOCUS ON ATMOSPHERE-SURFACE EXCHANGE}

OYCE is embedded in a scientifically highly interdisciplinary environment. The Geoverbund $A B C / J$ (www.geoverbund-abcj.de) - founded in 2009 and hosting JOYCE-connects the geoscience departments at the universities RWTH Aachen, Bonn, and Cologne and at the Forschungszentrum Jülich in order to coordinate both scientific cooperation and university education.

The Transregional Collaborative Research Centre TR32 Patterns in Soil-Vegetation-Atmosphere-Systems (Vereecken et al. 2010; http://tr32.de)—one of the initiators of JOYCE-started in 2007 to investigate the groundwater-soil-vegetation-atmosphere continuum by integrating monitoring of system parameters, states, and fluxes with modeling and data assimilation in order to reach a holistic view of the terrestrial system. TR32 develops novel observations techniques and multiscale integrated models (Shrestha et al. 2014) to predict the evolution of regional terrestrial systems. JOYCE is the central pillar for connecting cloud property development and land surface-atmosphere exchange processes. JOYCE is also embedded in the Rur catchment terrestrial observatory belonging to Terrestrial Environmental Observatories (TERENO; Zacharias et al. 2012; http://teodoor.icg.kfa-juelich.de) funded by the
German Helmholtz Association, which monitors and catalogues the long-term (>10 years) ecological, social, and economic impact of global change at the regional level. Among many others, this interdisciplinary environment complements JOYCE observations by

- two polarimetric X-band weather radars-JuXPol operated by TERENO located on the Sophienhöhe mountain, a hill created from open-pit mining, roughly $200 \mathrm{~m}$ above the surrounding terrain (about $3 \mathrm{~km}$ to the east of JOYCE) and BoXPol operated by TR32 at the university of Bonn (about $50 \mathrm{~km}$ to the southeast of JOYCE), which both allow continuous monitoring of the temporal and spatial evolution of precipitation in the $100-\mathrm{km}$ vicinity of JOYCE;

- an MRR network accompanied by disdrometers and rain gauges of TR32 designed to calibrate the $\mathrm{X}$-Band radars and develop precipitation retrieval algorithms; and

- spatially high- and low-resolution in situ sensor networks and neutron probes for monitoring soil moisture evolution including seven eddy covariance flux towers distributed over differently cultivated areas offering the potential for studying atmosphereland surface interactions on different scales.

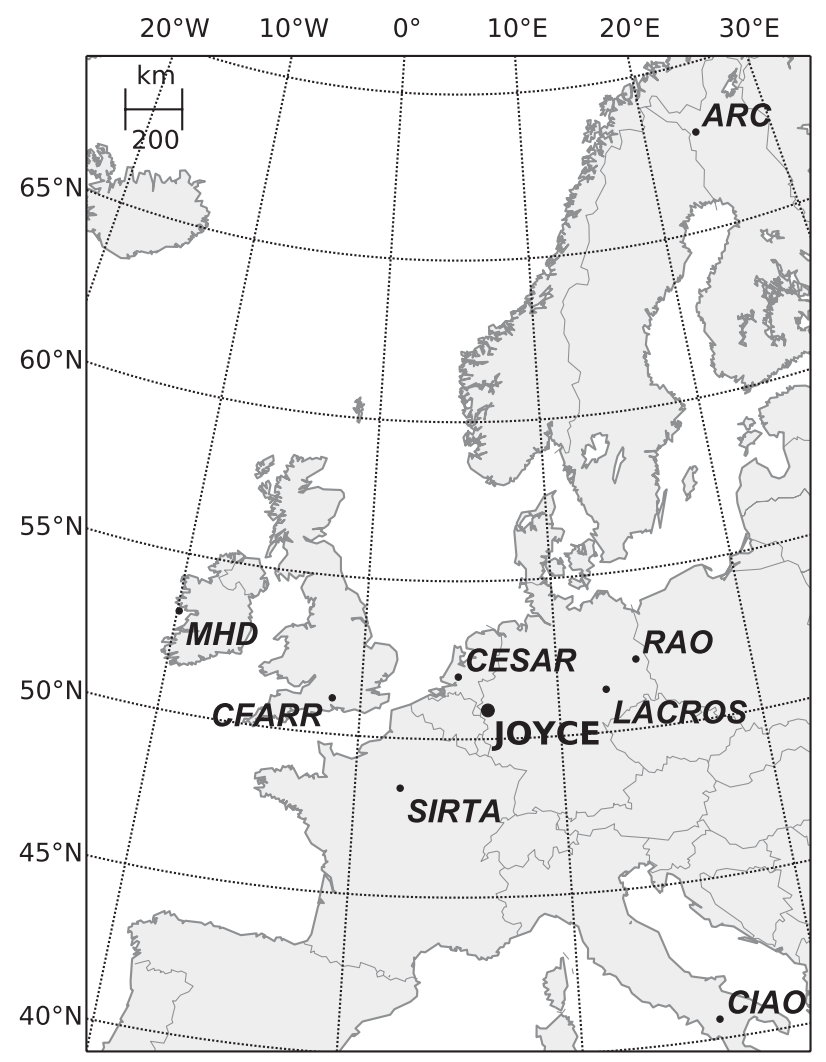

FIG. I. JOYCE and its location within central Europe. Also shown: other, similar European atmospheric observatories. about $3 \mathrm{~km}$ away, the closest hilly, mostly forested elevations $(<500 \mathrm{~m})$ are about $15 \mathrm{~km}$ away toward the southwest. Monthly average temperatures are between $3.1^{\circ} \mathrm{C}$ (January) and $18.1^{\circ} \mathrm{C}$ (July), the zonally dominated wind direction ranges from $220^{\circ}$ to $290^{\circ}$ about $50 \%$ of the time, and annual precipitation has values from 440 to $1,040 \mathrm{~mm}$ (all values from 1992 to 2014).

JOYCE is operated jointly by the Institute for Geophysics and Meteorology at the University of Cologne and the Institute of Energy and Climate Research (IEK-8) at FZJ. The measurements at JOYCE have commenced from 2009 onward (Table 1) and it is planned to keep them running long term into the future (i.e., to set the stage for climate monitoring by ground-based remote sensors). Most remote sensing instruments are capable of full-hemispheric scanning in arbitrary azimuth and elevation directions, which allows a 3D view of the temporal evolution of clouds and their environment.

JOYCE is embedded in an international network of atmospheric observatories, which focus on detailed observations of the atmospheric column. Within Germany, these observations are harmonized within High Definition Clouds and Precipitation 
TABLE I. JOYCE key instrumentation; see also www.geomet.uni-koeln.de/joyce. Note that $\Delta z$ and $\Delta t$ denote vertical and temporal resolutions, respectively.

\begin{tabular}{|c|c|c|c|c|}
\hline $\begin{array}{c}\text { Instrument } \\
\text { (measured since) }\end{array}$ & Principle & $\begin{array}{c}\text { Measurement } \\
\text { quantity }\end{array}$ & Specification & $\begin{array}{l}\text { Atmospheric } \\
\text { variables }\end{array}$ \\
\hline AERI (May 20II) & $\begin{array}{l}\text { Atmospheric } \\
\text { Emitted Radiance } \\
\text { Interferometer }\end{array}$ & $\begin{array}{l}\text { Radiance spectrum } \\
\text { between } 3,020 \\
\text { and } 520 \mathrm{~cm}^{-1} \\
(3.3-19 \mu \mathrm{m})\end{array}$ & $\begin{array}{l}\text { Vertically staring, } \\
\Delta t \sim 20 \mathrm{~s}, 5,000 \\
\text { channels with } 1-\mathrm{cm}^{-1} \\
\text { resolution }\end{array}$ & $\begin{array}{l}\text { Temperature and } \\
\text { humidity profiles, } \\
\text { aerosol type, cloud } \\
\text { optical depth, and } \\
\text { effective radius }\end{array}$ \\
\hline $\begin{array}{l}\text { Ceilometer } \\
\text { CHMI5k } \\
\text { (Mar 20I3) }\end{array}$ & $\begin{array}{l}\text { Light detecting and } \\
\text { ranging (lidar) }\end{array}$ & $\begin{array}{l}\text { Backscatter profiles } \\
\text { at I,064 nm up to } \\
\text { I5 km }\end{array}$ & $\begin{array}{l}\text { Fixed viewing angle, } \\
\Delta \mathrm{z}=15 \mathrm{~m}, \Delta t=15 \mathrm{~s}\end{array}$ & $\begin{array}{l}\text { Cloud-base height, } \\
\text { mixing-layer height, } \\
\text { aerosol layers }\end{array}$ \\
\hline $\begin{array}{l}\text { Ceilometer } \\
\text { CT25K (Oct 2010) }\end{array}$ & Lidar & $\begin{array}{l}\text { Backscatter profiles } \\
\text { at } 905 \mathrm{~nm} \text { up to } 7 \\
\mathrm{~km}\end{array}$ & $\begin{array}{l}\text { Fixed viewing angle, } \\
\Delta z=30 \mathrm{~m}, \Delta t=15 \mathrm{~s}\end{array}$ & $\begin{array}{l}\text { Cloud base height, } \\
\text { mixing layer height, } \\
\text { aerosol layers }\end{array}$ \\
\hline $\begin{array}{l}\text { Doppler lidar } \\
\text { Streamline } \\
\text { (Nov 2009) }\end{array}$ & Doppler lidar & $\begin{array}{l}\text { Backscatter and } \\
\text { Doppler velocity } \\
\text { profiles at I,500 nm } \\
\text { up to } 9 \mathrm{~km}\end{array}$ & $\begin{array}{l}\text { Fully scanable } \\
\text { (elevation and azimuth), } \\
\Delta \mathrm{z}=30 \mathrm{~m}, \Delta t \sim 2 \mathrm{~s}\end{array}$ & $\begin{array}{l}\text { Horizontal and } \\
\text { vertical wind vector } \\
\text { profiles, mixing-layer } \\
\text { height, cloud and } \\
\text { aerosol layers }\end{array}$ \\
\hline $\begin{array}{l}\text { HATPRO } \\
\text { (Jul 20I0) }\end{array}$ & $\begin{array}{l}\text { Passive microwave } \\
\text { radiometer and } \\
\text { broadband IR } \\
\text { radiometer }\end{array}$ & $\begin{array}{l}\text { Brightness } \\
\text { temperature }\end{array}$ & $\begin{array}{l}\text { Fully scanable } \\
\text { (elevation and azimuth), } \\
\text { I4-channel microwave } \\
\text { profiler at } 22-3 \mid \text { and } \\
5 \mathrm{I}-58 \mathrm{GHz} \text {, IR channels } \\
\text { centered at II.I and } \\
\mathrm{I} 2.0 \mu \mathrm{m}\end{array}$ & $\begin{array}{l}\text { Temperature and } \\
\text { humidity profiles, } \\
\text { LWP, IWV, cloud-base } \\
\text { temperature }\end{array}$ \\
\hline $\begin{array}{l}\text { MIRA-36 } \\
\text { (Mar 20II) }\end{array}$ & $\begin{array}{l}\text { Polarimetric and } \\
\text { Doppler capable } \\
\text { pulsed Ka-band } \\
\text { cloud radar }\end{array}$ & $\begin{array}{l}\text { Doppler spectrum, } \\
\text { radar reflectivity, } \\
\text { Doppler velocity, } \\
\text { spectral width, linear } \\
\text { depolarization ratio }\end{array}$ & $\begin{array}{l}\text { Fully scanable } \\
\text { (elevation and azimuth) } \\
\text { measurements at } \\
35.5 \mathrm{GHz} \text {, minimum } \\
\text { detectable reflectivity } \\
\text { factor of } \sim 45 \mathrm{dBZ} \\
\text { at } 5-\mathrm{km} \text { range, } \\
\text { and integration } \\
\text { time }=0.1 \mathrm{~s}\end{array}$ & $\begin{array}{l}\text { Cloud boundaries, } \\
\text { cloud phase, } \\
\text { precipitation, } \\
\text { microphysical } \\
\text { properties }\end{array}$ \\
\hline TSI (Sep 2009) & $\begin{array}{l}\text { Camera viewing a } \\
\text { spherical mirror } \\
\text { reflecting the } \\
\text { whole sky }\end{array}$ & $\begin{array}{l}\text { RGB hemispheric } \\
\text { image }(288 \times 352 \\
\text { pixels })\end{array}$ & $\begin{array}{l}\Delta t=20 \mathrm{~s}, \Delta \theta=0.6^{\circ} \\
\text { at zenith, hemispheric } \\
\text { image down to } 3^{\circ} \\
\text { elevation }\end{array}$ & $\begin{array}{l}\text { Cloud cover, } \\
\text { hemispheric cloud } \\
\text { distribution, cloud } \\
\text { type (thin or opaque) }\end{array}$ \\
\hline
\end{tabular}

for Advancing Climate Prediction ${ }^{1}\left[\mathrm{HD}(\mathrm{CP})^{2}\right]$ - a research program to improve our understanding of cloud and precipitation processes and their implication for climate prediction. Europe-wide, these activities are coordinated within the Aerosols, Clouds, and Trace Gases Research Infrastructure Network (ACTRIS), which is a European project aimed at integrating European ground-based stations equipped with advanced atmospheric-probing instrumentation for aerosols, clouds, and short-lived gas-phase species. ACTRIS and $\mathrm{HD}(\mathrm{CP})^{2}$ collaborate closely with the U.S. Atmospheric Radiation Measurement (ARM) Climate Research Facility (Mather and Voyles 2013) to ensure compatibility of data and products to guarantee common access for weather and climate scientists worldwide in a joint U.S.-EU data portal. ${ }^{2}$

\footnotetext{
' www.hdcp2.eu/

2 http://useu.ornl.gov/cap/
} 
JOYCE is equipped with similar instrumentation as the ARM and other ACTRIS cloud profiling sites (Fig. 1), thus providing observations for improving the representation of continental, midlatitude clouds and precipitation in a humid and highly industrialized region. One distinct research focus is on the interaction of clouds and precipitation with atmosphere-surface exchange processes (see "Focus on atmosphere-surface exchange") carried out within the Transregional Collaborative Research Center TR32 Patterns in Soil-Vegetation-Atmosphere Systems. ${ }^{3}$ This implies a need for a thorough insight on cloud evolution within the boundary layer.

The following article is intended to provide an overview of the JOYCE observations and to highlight their potential for cloud-related process studies and model evaluation.

JOYCE INSTRUMENTATION. JOYCE combines several key remote sensing instruments (Fig. 2 ; Table 1) operating in a continuous mode with high temporal resolution. In $\mathrm{HD}(\mathrm{CP})^{2}$, the sustained and publically open availability of long-term JOYCE data are planned through the Integrated Climate Data Center (ICDC). ${ }^{4}$ Here, first JOYCE datasets can already be accessed. Specific datasets are also available on request through the corresponding author. Furthermore, visualization of current and recent data are available through the JOYCE website. ${ }^{5}$ Additionally, JOYCE is part of the German Research Foundation Risources ${ }^{6}$ (Research Infrastructure) portal dedicated to providing scientists with resources and services for planning and implementing research projects.

Statistics for one year of JOYCE data (March 2012-February 2013) reveal that the key instruments are available more than $90 \%$ of the time. However, precipitation events with significant amounts reaching the ground deteriorate the quality of the observations owing to wetting of the instrument optics, which can lead to unwanted attenuation or reflection effects.

Key instrumentation. The Ka-band polarimetric Doppler cloud radar MIRA-36 (METEK GmbH, Germany; Melchionna et al. 2008) transmits a linear polarized signal at $35.5 \mathrm{GHz}$ and receives co- and cross-polarized signals simultaneously. In this way,

\footnotetext{
${ }^{3}$ http://tr32.de

${ }^{4}$ https://icdc.zmaw.de/projekte/hdcp2.html

${ }^{5}$ www.geomet.uni-koeln.de/joyce

${ }^{6}$ http://risources.dfg.de/home_en.html
}

vertical profiles of reflectivity, Doppler velocity, Doppler spectral width, and linear depolarization ratio are detected from $150 \mathrm{~m}$ to $15 \mathrm{~km}$ above ground. Given these measurements, information on the macrophysical (cloud boundaries, type of cloud particles) and microphysical (e.g., liquid/ice water content, particle effective radius) properties of even small cloud droplets $(\sim 10 \mu \mathrm{m})$ can be derived. In addition, higher moments of the Doppler spectrum (i.e., kurtosis and skewness) as well as the right and left slopes of the peak of the spectrum are calculated (Kollias et al. 2007). These can provide further information on cloud and drizzle microphysical parameters. The radar is mostly operated in a vertically pointing mode but also has scanning capabilities in order to better capture the 3D structure of clouds.

The 14-channel microwave profiler Humidity and Temperature Profiler (HATPRO, Radiometer Physics $\mathrm{GmbH}$, Germany; Rose et al. 2005) is a networksuitable microwave radiometer that has similar scanning possibilities as the radar. It can observe column integrated water vapor content (IWV) with approximately $0.5-0.8 \mathrm{~kg} \mathrm{~m}^{-2}$ uncertainty and liquid water path (LWP) with accuracies on the order of 20-30 $\mathrm{g} \mathrm{m}^{-2}$ (Löhnert and Crewell 2003). The ability to detect low-LWP $\left(<30 \mathrm{~g} \mathrm{~m}^{-2}\right)$ clouds can be enhanced by including measurements from two broadband IR pyrometers measuring at 11.1 and $12 \mu \mathrm{m}$. While most measurements are carried out observing zenith, regular (about three times per hour) azimuth scans are performed to characterize the spatial IWV and LWP inhomogeneity (Schween et al. 2011). Hourly elevation scans (Crewell and Löhnert 2007) allow retrieving the temperature profile with accuracies from 0.5 to $1.5 \mathrm{~K} \mathrm{RMSE}$ in the lower troposphere (Löhnert and Maier 2012). Additionally, since the beginning of 2013, MIRA-36 and HATPRO have been performing simultaneous elevation scans perpendicular to the main wind direction for capturing the 2D cloud structure.

At JOYCE two ceilometers are deployed: a 905-nm CT25K (Vaisala Inc., Finland; Münkel et al. 2007) and a 1,064-nm CHM15k (Jenoptik GmbH, Germany; Heese et al. 2010) to provide the temporal evolution of attenuated backscatter $(\beta)$ profiles (Weitkamp $2005)$ and up to three cloud-base heights. While the CHM15k is more sensitive (15-15,000-m range), the CT25K (0-7,500-m range) is better suited to observe the near-field range as the full overlap for transmitting and receiving beams start directly above the instrument.

The Atmospheric Emitted Radiance Interferometer (AERI, ABB Analytical, Canada; Knuteson et al. 

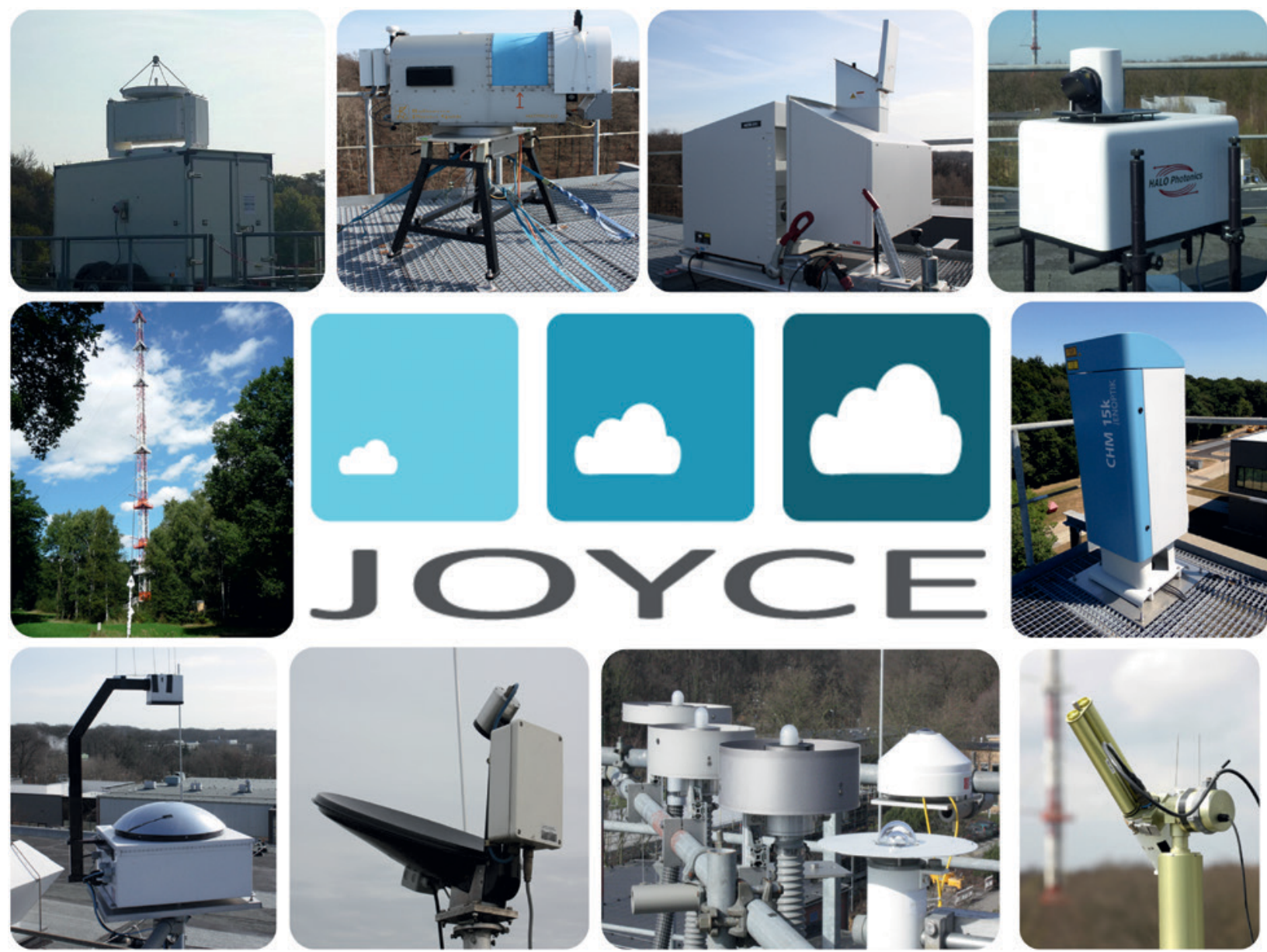

FIG. 2. Impression of selected JOYCE instruments. Clockwise from top left: cloud radar MIRA-36, microwave radiometer HATPRO, AERI, Doppler lidar Streamline, ceilometer CHM I5k, sun photometer CIMEL, radiation array, MRR, TSI, and I20-m meteorological tower.

2004a,b) is an infrared spectrometer that measures the downwelling infrared radiance from 3.3 to $19 \mu \mathrm{m}$ that contains information on the vertical profile of temperature and humidity. AERI is capable of acquiring data at approximately 20-s temporal resolution and thus can be utilized for thermodynamic profiling (temperature and humidity; Löhnert et al. 2009) and simultaneously retrieving microphysical cloud properties (Turner and Löhnert 2014) such as cloud optical depth and mean cloud effective radius.

The 1.5- $\mu \mathrm{m}$ Streamline Doppler lidar (HALO Photonics, Great Britain; Pearson et al. 2009) measures along-beam wind speeds in any arbitrary direction typically within the range of the atmospheric boundary layer (starting $75 \mathrm{~m}$ above the ground). Profiles of horizontal wind speed and direction are determined typically every 5 min by means of Doppler beam swinging. The rest of the time is used for vertical wind profiling $(w)$. Mixed-layer height is determined as a function of standard deviation of $w\left(\sigma_{w}\right)$ (Schween et al. 2014).
A Total Sky Imager (TSI 880, YES Inc., United States; Long et al. 2006) gives information on cloud cover and cloud type. It delivers a hemispheric image every $20 \mathrm{~s}$ as well as a corresponding cloud mask differentiating between clear sky, thin and opaque clouds, and total relative cloud cover for thin and opaque clouds. Besides the hemispheric image, all information (RGB values, cloud classification, and cloud cover) are extracted from almucantar apertures at $30^{\circ}$ and $45^{\circ}$ elevation in order to be analyzed together with corresponding azimuth scans of HATPRO and MIRA-36.

Auxiliary instruments and data. To complement the above-described key instrumentation, the JOYCE instrument suite also includes many auxiliary remote sensing and in situ measurements (see Table 2 for details). Additionally, Meteosat Second Generation (MSG) satellite data with 15-min resolution as well as MODIS/Medium Resolution Imaging Spectrometer (MERIS) overpasses over the site are regularly stored. 
ONE DAY OF MEASUREMENTS-BOUNDARY LAYER EVOLUTION. The field campaign $\mathrm{HD}(\mathrm{CP})^{2}$ Observational Prototype Experiment (HOPE) was carried out in 2013 with the goal of providing the observational basis for a critical model evaluation at scales smaller than $1 \mathrm{~km}$. Furthermore, it should provide information on subgrid variability and microphysical properties that are subject to parameterizations even at high-resolution simulations. During
April and May 2013, several intensive observation periods (IOP) were carried out where JOYCE instruments operated continuously in addition to numerous other remote sensors deployed to Jülich coming from different European partners. Here we concentrate on IOP7 on 25 April 2013 to introduce some of the diagnostics possible with JOYCE data. Eight radiosondes were launched during the course of the day to complement the remote sensing measurements. A high pressure

TABLE 2. JOYCE auxiliary instrumentation; see also www.geomet.uni-koeln.de/joyce.

\begin{tabular}{|c|c|c|c|c|c|}
\hline $\begin{array}{l}\text { Instrument, } \\
\text { manufacturer } \\
\text { (measured } \\
\text { since) }\end{array}$ & Principle & $\begin{array}{l}\text { Measurement } \\
\text { quantity }\end{array}$ & Specifications & $\begin{array}{l}\text { Atmospheric } \\
\text { variables }\end{array}$ & References \\
\hline $\begin{array}{l}\text { MRR by METEK, } \\
\text { Germany (Mar } \\
2012 \text { ) }\end{array}$ & $\begin{array}{l}\text { FMCW } \\
\text { Doppler radar }\end{array}$ & $\begin{array}{l}\text { Doppler } \\
\text { spectrum at } \\
\text { 24.1 GHz }\end{array}$ & $\begin{array}{l}\text { Robust, compact, } \\
\text { low power ( } 50 \\
\mathrm{~mW}) \text {, sensitivity } \\
>-5 \mathrm{dBZ} \text { at } 300-\mathrm{m} \\
\text { range }\end{array}$ & $\begin{array}{l}\text { Profiles of } \\
\text { rain drop size } \\
\text { distribution, rain } \\
\text { rate }\end{array}$ & $\begin{array}{l}\text { Peters et al. } \\
(2002)\end{array}$ \\
\hline $\begin{array}{l}\text { Parsivel } \\
\text { disdrometer by } \\
\text { OTT, Germany } \\
\text { (Apr 20I3) }\end{array}$ & $\begin{array}{l}\text { Optical } \\
\text { disdrometer }\end{array}$ & $\begin{array}{l}\text { Attenuation } \\
\text { of a diode- } \\
\text { maintained } \\
\text { "light sheet" } \\
\text { during passage } \\
\text { of a falling } \\
\text { particle }\end{array}$ & $\begin{array}{l}\text { Time and degree } \\
\text { of attenuation gives } \\
\text { information on fall } \\
\text { velocity and size of } \\
\text { particle }\end{array}$ & $\begin{array}{l}\text { Fall velocity } \\
\text { spectra }(0.1-20 \\
\left.\mathrm{m} \mathrm{s}^{-1}\right) \text {, drop } \\
\text { size distribution } \\
(0.3-30 \mathrm{~mm}), \\
\text { hydrometeor } \\
\text { phase } \\
\text { classification }\end{array}$ & $\begin{array}{l}\text { Löffler-Mang and } \\
\text { Joss (2000) }\end{array}$ \\
\hline $\begin{array}{l}\text { Shortwave } \\
\text { and longwave } \\
\text { radiation } \\
\text { sensors by Kipp } \\
\text { and Zonen, } \\
\text { Netherlands } \\
\text { (Jan 20II) }\end{array}$ & $\begin{array}{l}\text { Pyranometer, } \\
\text { Pyrheliometer, } \\
\text { and } \\
\text { pyrgeometers }\end{array}$ & $\begin{array}{l}\text { See } \\
\text { atmospheric } \\
\text { variables }\end{array}$ & $\begin{array}{l}\text { Pyranometer: high } \\
\text { quality, secondary } \\
\text { standards, sun } \\
\text { tracker blocks } \\
\text { direct sunlight }\end{array}$ & $\begin{array}{l}\text { Diffuse, direct, } \\
\text { and total } \\
\text { shortwave and } \\
\text { longwave flux } \\
\text { densities }\end{array}$ & $\begin{array}{l}\text { www.wmo.int } \\
\text { /pages/prog/www } \\
\text { /IMOPI } \\
\text { publications } \\
\text { /CIMO-Guide } \\
\text { /Ed2008Up20I0 } \\
\text { /Part-I/WMO8 } \\
\text { _Ed2008_Partl } \\
\text { _Ch7_Up20I0 } \\
\text { _CORRI_en.pdf }\end{array}$ \\
\hline $\begin{array}{l}\text { Sun photometer } \\
\text { by CIMEL } \\
\text { Electronique, } \\
\text { France (Jun } \\
2012 \text { ) }\end{array}$ & $\begin{array}{l}\text { Multichannel } \\
\text { radiometer }\end{array}$ & $\begin{array}{l}\text { Spectral } \\
\text { radiance at } \\
340,380,440, \\
500,675,870 \text {, } \\
937,1,020 \text {, and } \\
1,640 \mathrm{~nm}\end{array}$ & $\begin{array}{l}\text { AERONET } \\
\text { instrument, } \\
\text { direct sun and } \\
\text { sky radiance } \\
\text { measurements } \\
\text { according to a } \\
\text { prescribed schedule }\end{array}$ & $\begin{array}{l}\text { Aerosol optical } \\
\text { depth, liquid } \\
\text { cloud optical } \\
\text { depth and } \\
\text { effective radius, } \\
\text { integrated water } \\
\text { vapor }\end{array}$ & $\begin{array}{l}\text { Holben et al. } \\
\text { (1998); http:// } \\
\text { aeronet.gsfc.nasa. } \\
\text { gov }\end{array}$ \\
\hline $\begin{array}{l}\text { I20-m } \\
\text { meteorological } \\
\text { tower (I964) }\end{array}$ & $\begin{array}{l}\text { PT-100, cup } \\
\text { anemometers, } \\
\text { wind } \\
\text { vanes, hair } \\
\text { hygrometers, } \\
\text { gauges }\end{array}$ & $\begin{array}{l}\text { See } \\
\text { atmospheric } \\
\text { variables }\end{array}$ & $\begin{array}{l}\text { I0-min averages } \\
\text { at eight heights } \\
\text { between } 2 \text { and I } 20 \\
\mathrm{~m} \text {, tower located } \\
340 \text { m away from } \\
\text { other JOYCE } \\
\text { instruments }\end{array}$ & $\begin{array}{l}\text { Temperature, } \\
\text { wind, humidity, } \\
\text { surface } \\
\text { precipitation and } \\
\text { pressure }\end{array}$ & $\begin{array}{l}\text { www.fz-juelich.de } \\
\text { /gs/DE/UeberUns } \\
\text { /Organisation/S-U } \\
\text { /Meteorologie } \\
\text { /wetter/wstation } \\
\text { _node.html }\end{array}$ \\
\hline
\end{tabular}


system was dominating the weather situation in central Europe with westerly winds in the middle and upper troposphere and winds in the boundary layer alternating from westerly to southwesterly directions during the course of the day as measured by the radiosonde ascents (not shown) as well as by the Doppler lidar (Fig. 3, top). The Doppler lidar also detects the temporal growth of the mixed-layer height derived from the standard deviation of the vertical velocity variance (Fig. 3, bottom) with an onset between 0800 and 0900 UTC. The growth is rather continuous until around 1130 UTC when first convective clouds begin to form denoting that the rising air parcels have reached the cumulus condensation level. After 1400 UTC, the mixed-layer height is difficult to detect by the Doppler lidar because cloud cover is reducing solar insulation, leading to horizontally inhomogeneous surface heating, a reduced number of convective plumes, and more intermittent vertical movement. This results in a more complex structure in the vertical velocity variance.

Clouds. In the early morning after sunrise ( 0430 UTC), TSI retrievals (Fig. 4, middle) show a cloud cover of close to $100 \%$ due to a midlevel altocumulus cloud. Correspondingly, the Cloudnet classification (see "Cloudnet categorization scheme" for more information) shows a mixed-phase cloud with vertical extent of 200-300 $\mathrm{m}$ and varying cloud-base height (2,750-3,750 m) (Fig. 4, top), which disappeared completely around 1000 UTC as also confirmed by the TSI. Ice virga protruding from this cloud between 0600 and 0800 UTC is also visible. Temporal and spatial variability of typical cumulus humilis clouds can be nicely observed in the TSI time-azimuth display (Fig. 4, bottom) after 1300 UTC with maximum cloud amount observed around 1500 UTC. The azimuthtime display also helps to identify advection of clouds visible by the sinelike pattern (1300-1900 UTC) when clouds move from southwest to northeast.
Stratification. The boundary layer evolution in the vertical can be further characterized via time-height sections of potential temperature (Fig. 5, top) as derived from a HATPRO instrument. Close to the surface, the temperature retrieval has a very good vertical resolution (10-50 m), which, however, rapidly decreases with height. At midnight, the day begins with a very shallow stable nocturnal boundary layer, which increases in vertical extent until 0600 UTC because of longwave surface cooling. After sunrise, the surface slowly starts to warm up, but the nocturnal boundary layer dissolves only around 0730 UTC when the potential temperature $\theta$ in the lower $100 \mathrm{~m}$ becomes constant with height. From this time onward, a growing mixed layer can be observed, reaching its maximum height around 1400 UTC with constant $\theta$ up to about $1.5 \mathrm{~km}$. Correspondingly, mixed-layer height retrievals from Doppler lidar and ceilometer show a rapid increase. Note that the ceilometer falsely detects the mixed-layer height between 0700 and 0900 UTC around $750 \mathrm{~m}$, whereas mixed-layer height from the Doppler lidar starts increasing from levels around $100 \mathrm{~m}$ significantly only after 0900 UTC. This is due to enhanced backscatter from an aerosol layer, which in this case does not correspond to the actual 

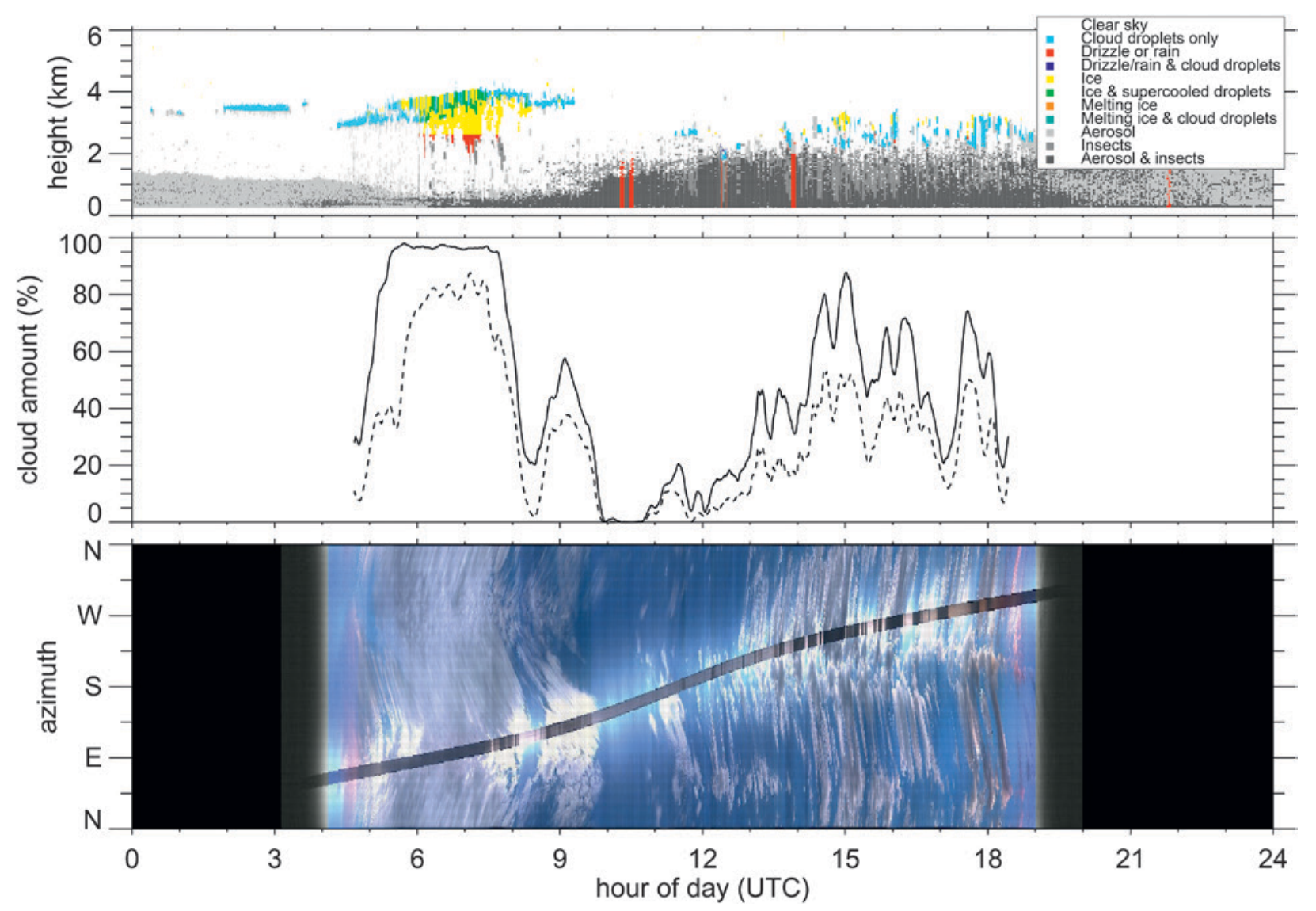

FIG. 4. (top) Cloudnet pixel classification on 25 Apr 2013, based on the Cloudnet target categorization scheme (see "Cloudnet categorization scheme" for details). Temporal and vertical grids correspond to $30 \mathrm{~s}$ and $30 \mathrm{~m}$, respectively. (middle) Cloud amount from TSI from all cloudy pixels (solid line) and opaque clouds only (dashed line) at $30^{\circ}$ elevation. Time series are smoothed with a gliding arithmetic average over $10 \mathrm{~min}$. (bottom) TSI time-azimuth section; each column represents a scan line at $30^{\circ}$ elevation from the whole-sky image at the respective time.

mixed-layer height (Schween et al. 2014). Finally, owing to longwave cooling at the surface, a new nocturnal boundary layer forms around 1800 UTC (i.e., $45 \mathrm{~min}$ before sunset at 1845 UTC).

The local gradient (Fig. 5, bottom) of potential temperature can additionally provide information on atmospheric stratification. It shows the largest absolute values at the surface with neutral stratification $\left(|d \theta / d z|<0.5 \mathrm{~K} \mathrm{~km}^{-1}\right)$ occurring only for less than an hour around 0715 and 1830 UTC: that is, $3.5 \mathrm{~h}$ after sunrise and about $1 \mathrm{~h}$ before sunset. These times mark end and beginning of the nocturnal boundary layerrespectively the beginning and the end of the mixed layer. The strongest unstable conditions close to the surface are observed between 0900 and 1300 UTC $\left(d \theta / d z<-2 \mathrm{~K} \mathrm{~km}^{-1}\right)$. Mixed-layer height cannot be resolved from HATPRO retrievals as a maximum local gradient (i.e., inversion) because of the low vertical resolution above $1 \mathrm{~km}$; this information needs to be complemented by the Doppler lidar mixed-layer height retrievals. Nevertheless, the region close to neutral stratification $\left(|d \theta / d z|<0.2 \mathrm{~K} \mathrm{~km}^{-1}\right)$ indicates how the mixed layer develops and how it transforms into the residual layer. After stabilization at the surface at 1800 UTC, the mixed layer transforms into the residual layer remaining neutral until 2230 UTC when it suddenly stabilizes. Note that the slightly negative values within the residual layer $\left(d \theta / d z \sim-0.2 \mathrm{~K} \mathrm{~km}^{-1}\right)$ are also due to the limited vertical resolution of HATPRO, which can thus capture the actual neutral layer only to a certain extent.

Assuming an adiabatic ascent, convective plumes originating from the surface rise until their temperature cools to that of the surrounding air. This is represented by the bulk gradient of $\theta$ (i.e., the difference $\Delta \theta$ between height $i$ and the surface). Following the line of $\Delta \theta=0$ (Fig. 5 , bottom) we see a somewhat slower growth of the mixed layer before 0900 UTC when the nocturnal boundary layer is not yet fully dissolved and a rapid growth between 0900 and 1100 UTC. 


\section{CLOUDNET CATEGORIZATION SCHEME}

$A^{\mathrm{t} J O Y C E}$, the Cloudnet target categorization scheme A(Illingworth et al. 2007; www.cloud-net.org) presents an essential tool for deriving cloud macrophysical properties (i.e., cloud position, extent, and type) in the vertical column above the measurement site. Cloudnet originated as an EU FP5 project (200I-05) and is currently supported by the EU FP7 project ACTRIS. Input to the Cloudnet categorization scheme is composed of measurement data from the ceilometer, cloud radar, microwave radiometer and output from the DWD COSMO-DE model (www.cosmo-model.org/). Profiles of measured and modeled variables are converted to standardized units and are interpolated to the cloud radar data spatial and temporal grids. Each data pixel is categorized either as clear sky or aerosol and/or insects and/or cloud phase and whether it is precipitating. The lowest liquid cloud base (warm or supercooled) is identified from ceilometer backscatter profiles, while cloud top and precipitation are identified from cloud radar data. The phase of the falling hydrometeors is identified according to temperature: hydrometeors are likely to be ice when the wet-bulb temperature is below the freezing level. In addition to providing valuable information on cloud amount, the derived hydrometeor type is a crucial constraint for the application of variational cloud microphysical retrieval applications. The Cloudnet program package itself provides retrievals of liquid and ice water content (Hogan et al. 2006) and drizzle microphysical properties (O'Connor et al. 2005) namely, droplet size, number concentration, water content, and flux.
The maximum is reached around 1300 UTC, showing only some slight decrease until 1800 UTC, when the line suddenly returns to the ground, indicating that the end of convection occurs as a sudden breakdown rather than a continuous decrease in the height convective plumes can reach.

Water vapor fluctuations and turbulence. Water vapor fluctuations and turbulence are directly related to the appearance of clouds. A synopsis of high-temporalresolution IWV (from HATPRO) and vertical velocity (from Doppler lidar) observations is presented in Fig. 6. IWV remains fairly constant up to 1000 UTC at values between 25 and $26 \mathrm{~kg} \mathrm{~m}^{-2}$. At the same time, rather small IWV standard deviation (over $30 \mathrm{~min}$ ) values on the order of $0.1 \mathrm{~kg} \mathrm{~m}^{-2}$ are observed. However, IWV variability is doubled at 1000 UTC when the rapid growth of the mixed layer is detected and again increases to values larger than $0.2 \mathrm{~kg} \mathrm{~m}^{-2}$ during the times when cumulus clouds appear after 1300 UTC.

Values of $w$ and $\sigma_{w}$ have also been calculated, whereby the calculations are averaged over the mixed layer and a 30-min time span. After 0800 UTC, $\sigma_{w}$ steadily increases from values below $0.5 \mathrm{~m} \mathrm{~s}^{-1}$ to maximum values of almost $1.5 \mathrm{~m} \mathrm{~s}^{-1}$ shortly before clouds appear around 1300 UTC. After first clouds appear, $\sigma_{w}$ is reduced throughout the day owing to less intense solar insolation by cloud shading and increasing solar zenith angle. Interestingly, on this day the maximum values of $\sigma_{w}$ are mostly associated with mean, positive updraft velocities.
INSTRUMENT SYNERGY. Remote sensing measurements contain only a limited amount of information on the atmospheric state. In this context, an atmospheric retrieval can be characterized by its degrees of freedom (DOF) for signal: the number of independent pieces of information about atmospheric state variables (e.g., temperature profile) that can be extracted for a given set of measurements (Rodgers 2000). At maximum, this value is equal to the actual number of measurements (e.g., number of frequencies or observations angles), which practically never occurs owing to correlations between state variables, correlations between measurements, and uncertainties of the measurements. Synergetic combinations of measurements of the same atmospheric column with different sensitivities to atmospheric state variables may enhance the overall DOF (Ebell et al. 2013). An example is the integrated profiling technique (IPT) (Löhnert et al. 2008), which is applied at JOYCE by combining cloud radar, microwave radiometer, Cloudnet target categorization scheme, as well as a priori (i.e., climatology) information on the desired parameters. By combining these pieces of information based on the optimal estimation equations (Rodgers 2000), IPT retrieves physically consistent profiles of temperature, water vapor, liquid water content (LWC), effective radius (Reff) of liquid water clouds, and the corresponding uncertainties.

Between 1400 and 2000 UTC 25 April 2013, LWP retrieved from microwave radiometer alone shows values below $0.4 \mathrm{~kg} \mathrm{~m}^{-2}$ with three peaks exceeding 

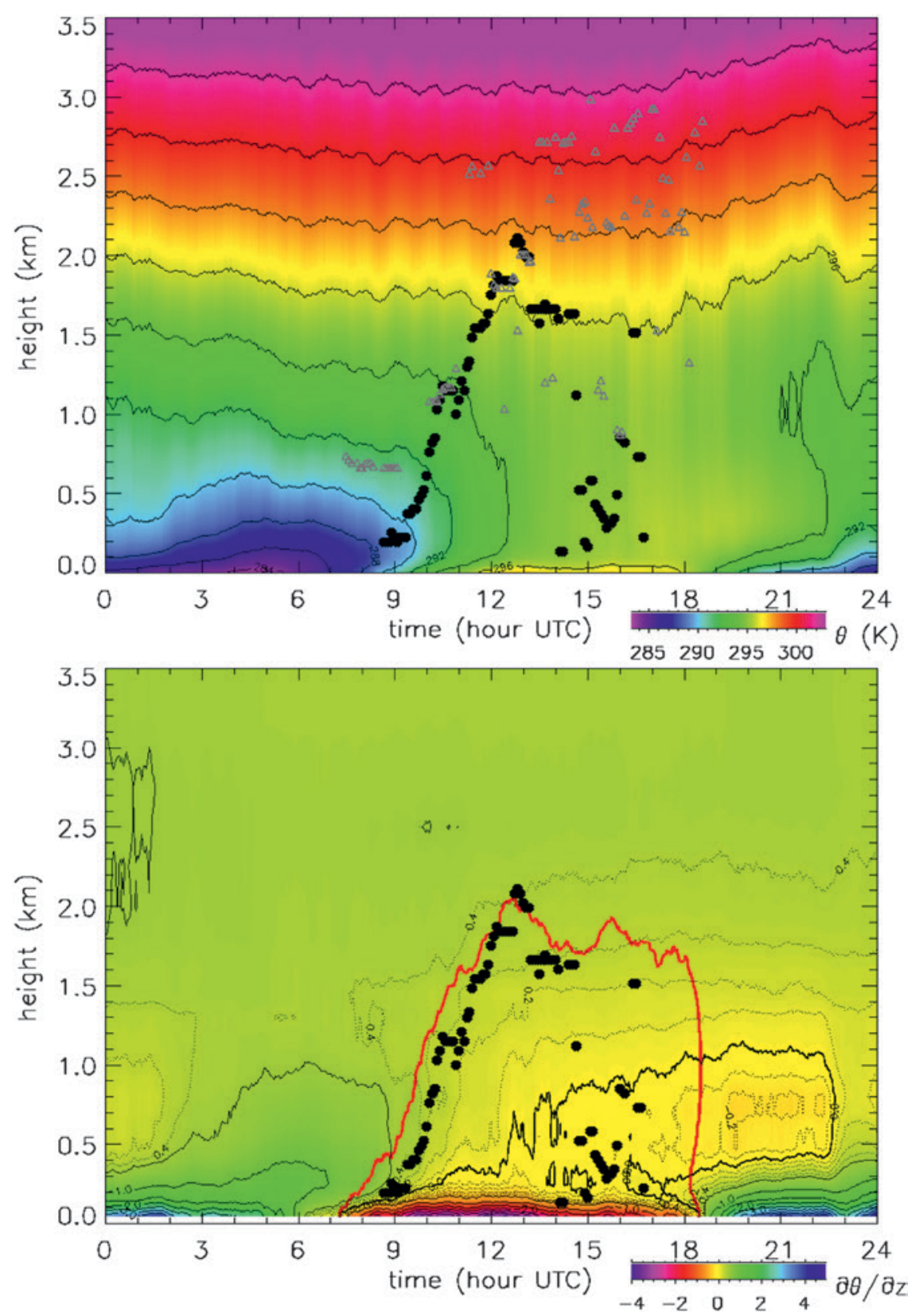

FIG. 5. (top) 24-h time-height display on 25 Apr 2013 of potential temperature $\boldsymbol{\theta}$ (colored contours) derived from an elevation scanning microwave radiometer ( 3-min resolution). Data have been smoothed over $30 \mathrm{~min}$. Black circles indicate mixing-layer height derived from Doppler lidar (see Fig. 3), whereas gray triangles indicates mixing-layer height retrieved by ceilometer. (bottom) As in (top), except that now the local vertical gradient of $\theta\left(\mathrm{K} \mathrm{km}^{-1}\right)$ is shown, whereby the thick black solid line shows the zero line (dry neutral). The red line indicates the height of the mixed layer according to the parcel method (i.e., the height where the bulk difference of $\theta$ between $z$ and at $z_{\text {ref }}=0 \mathrm{~m}$ is equal to zero). above cloud base ( $2 \mathrm{~km})$ by strong lateral mixing and a strong inversion near $3 \mathrm{~km}$ (visible in the afternoon radiosondes). The clouds with the largest vertical extent $(\sim 800 \mathrm{~m})$ and the highest LWC values can be related to the LWP peaks around 1450, 1600, and 1750 UTC.

From the cloud boundaries, pressure, and temperature given by Cloudnet target categorization, the adiabatic liquid water content $\left(\mathrm{LWC}_{\mathrm{ad}}\right)$ of the cloud can also be calculated, which can be interpreted as the maximum liquid water content a cloud can obtain considering the adiabatic ascent of a parcel that experiences saturation with respect to liquid water and maintains all of its liquid water (no sedimentation or precipitation). Here, we define the dilution factor (DF) of a liquid cloud as $\left(1-\mathrm{LWP}_{\mathrm{LWP}}\right.$ ad with $\mathrm{LWP}_{\text {ad }}$ indicating the columnar value of $\mathrm{LWC}_{\mathrm{ad}}$. Theoretically, DF should range between 0 and 1 with values below 0.5 indicating more adiabatic clouds in their early development phase and DF values above 0.5 indicating that clouds have been exposed to turbulent entrainment of drier air of the surrounding. The few cases with DF around -0.5 (1450, 1700, and 1840 UTC) that imply LWP $>$ LWP $_{\text {ad }}$ can be attributed to spatialtemporal mismatching of the observations.

this limit (Fig. 7). IPT can be used to derive the corresponding vertically resolved LWC profiles and reveals the high vertical variability of boundary layer clouds. Observed lower cloud boundaries vary in the range of 2.1-2.9 km, which is due to broadening of the clouds
Two periods of intensified initial cloud development can be identified between 1450 and 1610 UTC and between 1730 and 1820 UTC with DF frequently reaching values around 0 (Fig. 7). Between 1400 and 2000 UTC, DF values are mostly larger than 


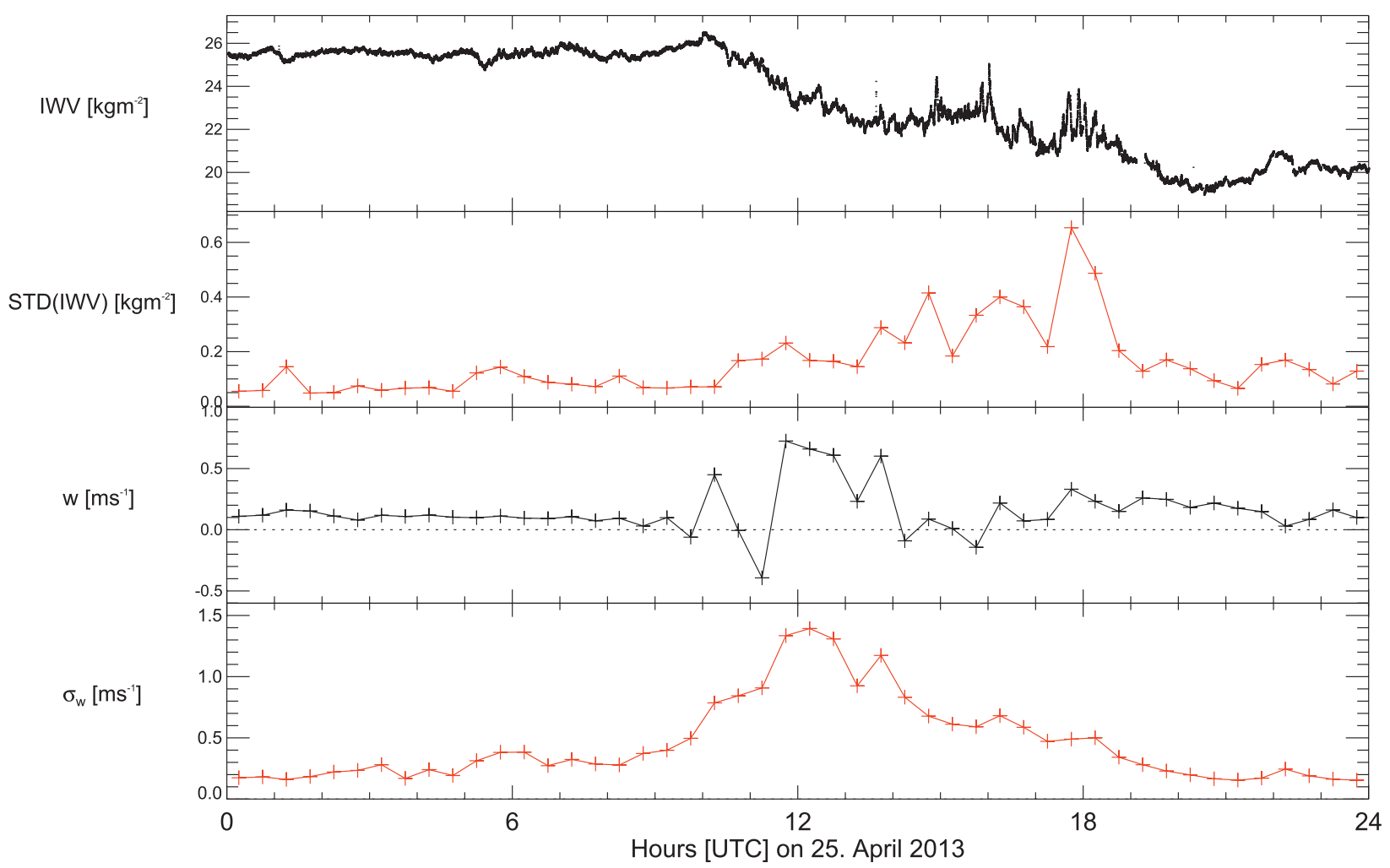

FIG. 6. (top)-(bottom) 24-h time series on 25 Apr 2013 of microwave-radiometer-derived IWV, standard deviation of IWV over $30 \mathrm{~min}$, and mean and standard deviation of vertical velocity from Doppler lidar averaged over $30 \mathrm{~min}$ and from surface to top of the mixed layer.

0.5 , indicating cloud decay. The times of intensified cloud development also mostly correspond to positive values of vertical velocity in the lowest $100 \mathrm{~m}$ below cloud base (e.g., between 1720 and 1810 UTC), which is consistent with the assertion of cumulus clouds developing through updrafts.

LONG-TERM JOYCE DATA ANALYSIS. In addition to providing important data for process studies in the cloudy boundary layer, long-term JOYCE observations also bear potential for the improvement of parameterization schemes in numerical weather and climate prediction models; for example, Barrett et al. (2009) have shown how ground-based remote sensing observations of radar and lidar have been used to evaluate and improve parameterization schemes of the cloudy boundary layer. As an example, we show JOYCE observations for monitoring the diurnal cycle of water vapor variability, cloud dilution factor, and the autoconversion process (i.e., precipitation onset in liquid clouds)-subgrid-scale processes that should be captured adequately by parameterization schemes in the numerical models. Additionally, the role of ice in surface precipitation is characterized statistically.
How variable is water vapor? Dai et al. (2002) show that specifically in summer and in the lower troposphere, surface evapotranspiration, vertical mixing, low-level moisture convergence, and precipitation all affect the diurnal variation of water vapor in the central and eastern United States, although the diurnal amplitude is generally small (less than $5 \%$ of the mean). All of these processes regulate the evolution of boundary layer clouds.

HATPRO-derived IWV averages have been calculated over hourly bins during water-cloudfree scenes as a function of season (Fig. 8) using data between January 2011 and November 2013 encompassing 200-400 analyzed cases depending on the time of day. As expected, average values in winter $\left(\sim 7 \mathrm{~kg} \mathrm{~m}^{-2}\right)$ are much smaller than those in summer (20-24 $\left.\mathrm{kg} \mathrm{m}^{-2}\right)$ and spring and fall in between. Only in summer, a diurnal cycle with an amplitude of about $2 \mathrm{~kg} \mathrm{~m}^{-2}(10 \%)$ with respect to the seasonal average can be observed. However, a much clearer signal in the diurnal cycle in summer can be observed for the standard deviation of IWV (also calculated over $1 \mathrm{~h}$ ) with maximum values above $0.25 \mathrm{~kg} \mathrm{~m}^{-2}$ during the day and only $50 \%$ of this value during nighttime. In spring and fall, only 


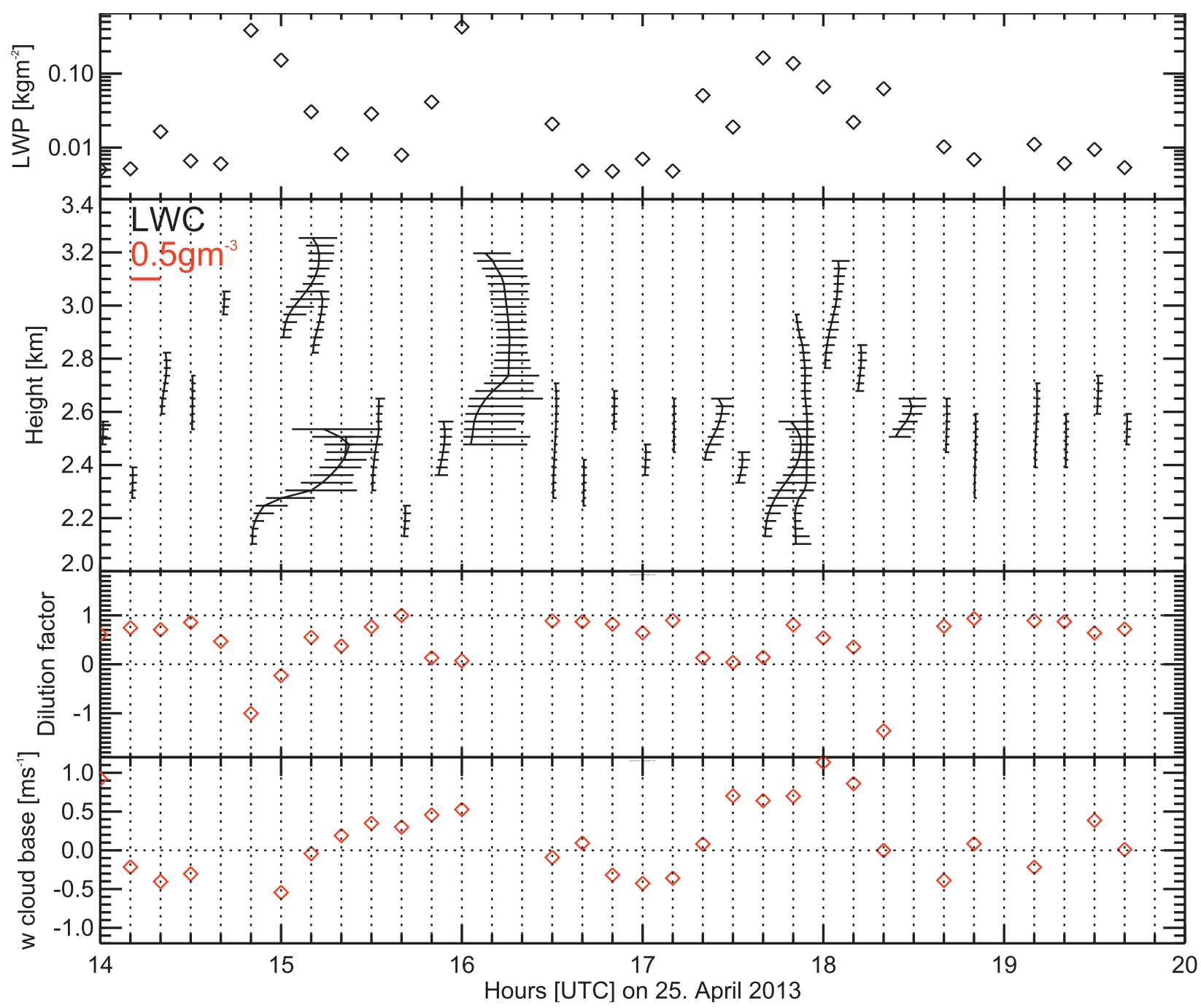

FIG. 7. (top)-(bottom) 6-h time series on 25 Apr 2013 of microwave-radiometer-derived LWP, LWC profiles derived with IPT (only the first derived LWC profile within a 10-min interval is shown), corresponding cloud dilution factor (see text for details), and vertical velocity from Doppler lidar at $100 \mathrm{~m}$ below cloud base averaged over $60 \mathrm{~s}$.

a slight diurnal cycle in IWV standard deviation is visible, whereas in winter no diurnal cycle is visible with values ranging around $0.08 \mathrm{~kg} \mathrm{~m}^{-2}$. The midday peak during summer months can be largely attributed to the interaction of solar radiation with the surface leading to enhanced latent heat fluxes, higher turbulence, and thus a large IWV variability. The similar wintertime variability for day and night lets us conclude that the water vapor variability is then only weakly influenced by interactions between solar radiation and the surface. Spring and fall obviously present a transition time in this respect. In summary, the magnitude and temporal evolution of IWV variability may be used to evaluate model performance with respect to the development of the well-mixed boundary layer.
How adiabatic are low-level clouds? As mentioned in the section on "Instrument synergy," the DF of liquid water clouds is an indicator for the turbulent entrainment of drier air into the cloud. Campaignbased airborne measurements of LWC variability in continental nonprecipitating clouds have shown to be driven by variations in droplet number concentration [i.e., inhomogeneous mixing (Small et al. 2013)], which can have important impacts on the parameterization of cloud-radiation interactions (Pawlowska et al. 2000). Also, cloud-top mixing is believed to play a crucial role for precipitation initiation (Small and Chuang 2008) and differs significantly for stratus and cumulus clouds (Brenguier et al. 2011).

Here, a year (March 2012-February 2013) of JOYCE data including more than 8,600 nonprecipitating 

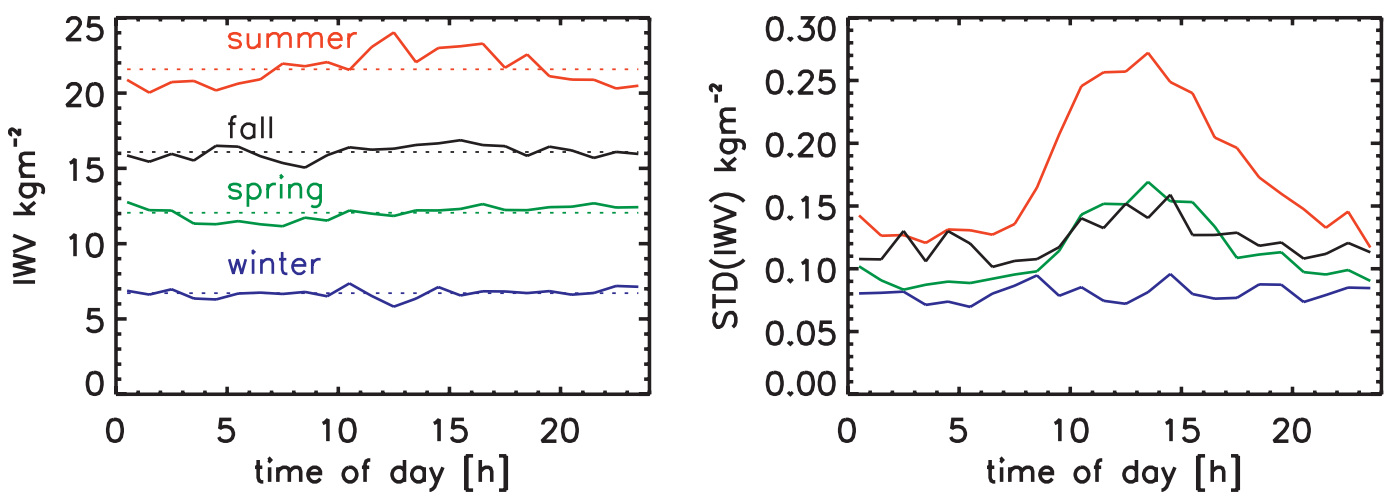

FIG. 8. (left) Mean IWV diurnal cycle (evaluated on an hourly basis) using only JOYCE clearsky data from Jan $201 \mathrm{I}$ to Nov 2013. The line colors correspond to different seasons and the dashed lines correspond to seasonal averages over all hours. (right) As in (left), except that the mean standard deviation over the corresponding hour bin is shown.

single-layer liquid water cloud profiles as identified by the Cloudnet categorization is analyzed toward dilution. The calculated LWP ${ }_{\text {ad }}$ is compared with the closest LWP values from HATPRO, which show that most clouds exhibit a significant amount of dilution. Only clouds with LWP $<\sim 0.15 \mathrm{~kg} \mathrm{~m}^{-2}$ (Fig. 9, left) show a nonzero probability of being purely adiabatic. As also shown by Karstens et al. (1994) through the analysis of aircraft in situ data, the absolute value of LWP deviation from the adiabatic value is generally higher for higher values of LWP. The DF can take any value from 0 to 1 in clouds with a vertical extent smaller than $300 \mathrm{~m}$, whereas clouds thicker than $500 \mathrm{~m}$ show a trend of increasing DF with vertical extent (Fig. 9, right), so that clouds with a vertical extent of $500 \mathrm{~m}$ will be diluted by at least $30 \%$, $1,000 \mathrm{~m}$ will be diluted by at least $60 \%$, and larger than $1,500 \mathrm{~m}$ will be diluted by at least $80 \%$. Note that next to spatial-temporal mismatches, LWP uncertainties can also lead to DF values greater than 1 (e.g., originating from retrievals where LWP $<0$ ). This is because of the LWP measurement accuracy of about $0.025 \mathrm{~kg} \mathrm{~m}^{-2}$ that leads to large relative errors in case of thin liquid water clouds.

When do clouds begin to precipitate? Autoconversion (Berry and Reinhardt 1974) is defined as the collision-coalescence of cloud droplets $(\sim 10-\mu \mathrm{m}$ radius) and plays an essential role in the transition of nonprecipitating to drizzling (small precipitation drops of about $25-50-\mu$ m radius) clouds at temperatures above $0^{\circ} \mathrm{C}$. Albrecht (1989) proposes that drizzle formation may influence the radiative impact of marine low-level liquid clouds on the climate system through the socalled second aerosol indirect effect, which assumes that a higher cloud droplet number concentration leads to a reduction of drizzle production and with that possibly to an increase in fractional cloudiness and LWC. However, empirical parameterizations of autoconversion in global circulation models (GCMs) based on cloud droplet number concentration and/ or LWC show large differences (Xu et al. 2005) and can lead to overestimations of the second indirect aerosol effect (Quaas et al. 2009). Mann et al. (2014) have also shown for continental single-layer warm clouds below $3 \mathrm{~km}$ that probability of precipitation increases with LWP, decreases with cloud condensation nuclei (CCN) number concentration, and that autoconversion dominated precipitation is more susceptible to aerosol perturbations than accretion dominated precipitation.

Characteristics of drizzling and nondrizzling clouds have also been observed with the JOYCE cloud radar and microwave radiometer. LWP and cloud vertical extent have been analyzed as a function of probability for precipitation for a 1-year analysis time period (March 2012-March 2013). Using the Cloudnet target categorization single-layer liquid clouds were discriminated by 1) containing no drizzle and 2) containing drizzle within their vertical boundaries (Fig. 10). It can be seen that a single-layer liquid cloud with a vertical extent smaller than $400 \mathrm{~m}$ and with LWP $<80 \mathrm{~g} \mathrm{~m}^{-2}$ practically never bears drizzle droplets, whereas clouds thicker than $600 \mathrm{~m}$ and with LWP $>250 \mathrm{~g} \mathrm{~m}^{-2}$ almost always contain drizzle.

These statistics rely on the rather simple Cloudnet precipitation detection algorithm based on the gradient of radar reflectivity. Currently, JOYCE activities concentrate on improving precipitation detection using additional moments of the cloud radar Doppler spectrum such as velocity, width, skewness, or kurtosis (Kollias et al. 2011a,b). This way, we expect 

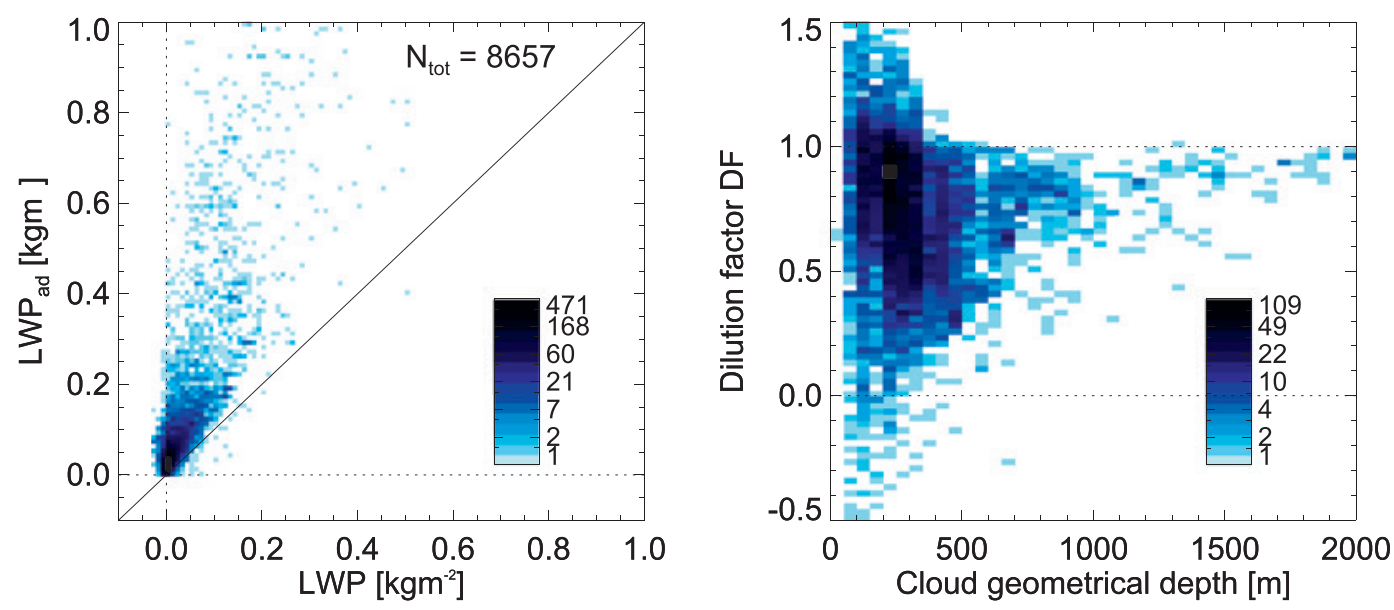

FIG. 9. (left) 2D histogram of adiabatic LWP $_{\text {ad }}$ using cloud boundary and temperature constraints as given by Cloudnet data vs microwave-radiometer-derived LWP for 8,657 detected single-layer liquid cloud cases in the time period between Mar 2012 and Feb 20I3. Analysis is carried out on the Cloudnet algorithm time grid ( 30 s). (right) 2D histogram of cloud vertical extent vs cloud dilution factor [DF; I - (LWP/LWP ${ }_{\text {ad }}$ )] using data as in (left). Color bars indicate numbers of occurrence.

to directly capture the instance of the onset of the autoconversion process.

Which type of precipitation process? The analysis of JOYCE measurements from March 2012 until August 2013 also allows for identifying the processes that lead to precipitation close to the surface: has precipitation evolved via the ice phase and liquid phase (cold rain; i.e., through the Wegener-Bergeron-Findeisen process; Korolev 2007) or solely by interactions between liquid drops (i.e., warm rain; Bowen 1950)? Because of frequent cloud-top temperatures less than $0^{\circ} \mathrm{C}$ at JOYCE, we expect mixed-phase transitions to play a dominant role.

The lowest range bin of the Micro Rain Radar $(\mathrm{MRR})$ at $300 \mathrm{~m}$ above ground is taken as a rain

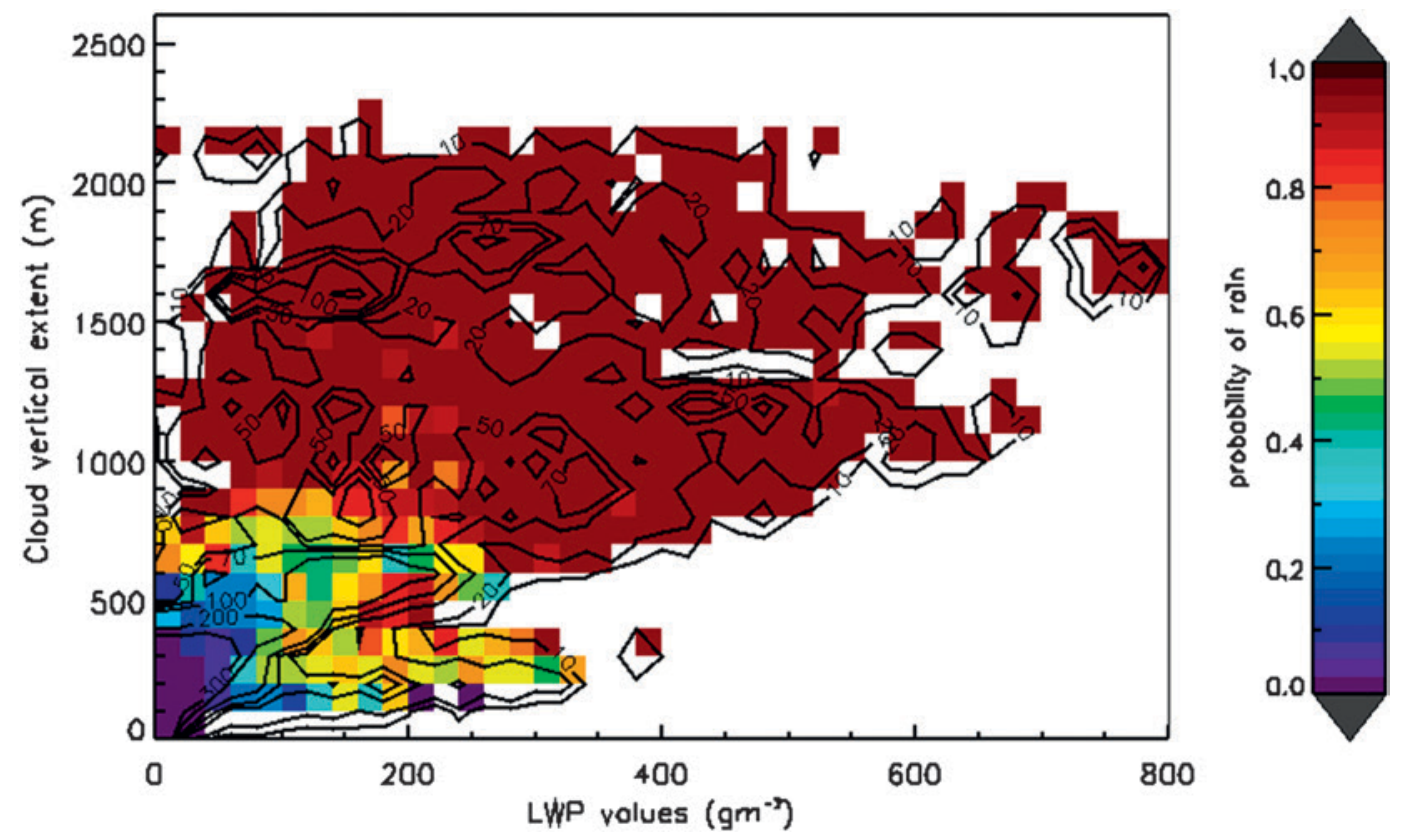

FIG. 10. 2D histogram for the probability of rain (colored) as a function of LWP and cloud vertical extent. Contours show total numbers of occurrence. Analysis is carried out for single-layer liquid water clouds only (as identified by the Cloudnet algorithm) from Mar 2012 to Feb 2013 encompassing a total number of 34,398 profiles. 
proxy for surface precipitation and is checked if rain rate exceeds a threshold value. If the threshold is exceeded, the Cloudnet scheme is checked for clouds in the column above. If the MRR bin is vertically connected to an ice cloud, precipitation is assumed to have developed via the ice phase; if no ice is connected, it is classified as rain via the liquid phase only. As expected and shown in Fig. 11, the analysis brings forth that the vast majority of precipitation is generated via the ice phase (97\%), whereas only in a small number of cases (3\%) rain is produced via liquid drop interactions only. For midlatitudes, this underlines the importance of a realistic modeling of ice clouds-specifically the cold rain process-in numerical models.

Additionally, Fig. 11 shows that $50 \%-60 \%$ of the total accumulated precipitation amount via ice phase originates from MRR rain rates less than $5 \mathrm{~mm} \mathrm{~h}^{-1}$ (i.e., light to moderate rain rates). If the MRR instrumental detection limit of $0.02 \mathrm{~mm} \mathrm{~h}^{-1}$ is used as lower bound for histogram evaluation, the total amount of precipitation is about $400 \mathrm{~mm}$ too high compared to the gauge measurements at the surface. While this could be explained by an MRR calibration offset, evaporation of low precipitation amounts from $300 \mathrm{~m}$ downward to the surface, as well as detection difficulties of rain rates less than
$1 \mathrm{~mm} \mathrm{~h}^{-1}$ by the gauge, must be taken into account. Thus, if rain rates lower than $1.5 \mathrm{~mm} \mathrm{~h}^{-1}$ are discarded from the MRR dataset, the gauge and MRR measurements coincide within $5 \%-10 \%$, giving total amounts of 945 and 1,023 mm, respectively, for March 2012 until August 2013.

SUMMARY AND OUTLOOK. The main objective of JOYCE is to improve our understanding of the cloudy boundary layer in a midlatitude environment. For this, continuous measurements with high temporal resolution are carried out that are specifically suited to characterize the diurnal cycle of water vapor, stability, and turbulence in the lower troposphere. In addition, instruments are set up to measure the micro- and macrophysical properties of clouds in detail and how they interact with the processes in the boundary layer as well as the large-scale synoptic situation. Employing the microwave radiometer, cloud radar, Doppler lidar, and ceilometer at JOYCE, the stratification of the lower boundary layer can be well described in addition to cloud macro- and microphysical quantities via synergetic retrieval methods. Clear signals of the increase in water vapor variability during the mixed-layer buildup are observed during summer months, as well as the probabilities of singlelayer liquid clouds to form drizzle as a function of the vertically integrated LWP and the cloud vertical extent. Also, first statistics show that in $97 \%$ of all cases leading to significant surface precipitation at JOYCE, ice is involved.

To investigate subcloud aerosol and cloud microphysical property interaction in the wellmixed boundary layer, a CCN observation system is currently being installed at the $120-\mathrm{m}$ meteorological tower of FZJ. Aerosol will be sampled by pumping dry air from the ground to three heights (124, 50 , and $3 \mathrm{~m}$ ). Three sampling lines along the tower will allow for measuring the subcloud aerosol properties, 
including size-resolved aerosol concentration, $\mathrm{CCN}$ activity parameter, and size-resolved $\mathrm{CCN}$ concentration.

In the next months and years, JOYCE observations will not only be used to evaluate parameterization schemes in NWP and climate models but also for input and assessment of large-eddy simulation (LES) models. Currently, an LES model is being set up to run continuously over JOYCE (Neggers et al. 2012). JOYCE measurements of wind, temperature, and humidity will allow the continuous forcing of the model. But the major accomplishment will be to investigate to what extent the LES clouds actually represent reality as measured by the JOYCE instruments. Because of the scanning potential of the major JOYCE instruments, this evaluation can be carried out for macrophysical and microphysical properties. These comparisons with respect to the environmental conditions at stake (e.g., synoptic forcing, aerosol conditions, surface boundary conditions) can then lead to a valuable source for improving cloud parameterization schemes not only in LES but also in climate models.

ACKNOWLEDGMENTS. The Transregional Collaborative Research Center TR32 Patterns in Soil-Vegetation-Atmosphere Systems, funded by the German Science Foundation (DFG), has contributed to the instrumentation of JOYCE and its maintenance. Further, the JOYCE boundary layer profiler (HATPRO) and AERI have been funded by DFG infrastructural programs under Grant INST 216/6811 and INST 216/519-1. The acquisition of further major instruments (MIRA-36 and Doppler lidar) was also supported by the German Federal State Nordrhein-Westfalen (Ministerium für Innovation, Wissenschaft und Forschung). Data management is funded by the research initiative High Definition Clouds and Precipitation for advancing Climate Prediction $\mathrm{HD}(\mathrm{CP})^{2}$ (first phase 2012-16) funded by the German Ministry for Education and Research (BMBF). Additionally, the contributions of the Ph.D. fellows Maria Barrera-Verdejo and Claudia Acquistapace have been supported by Initial Training for Atmospheric Remote Sensing (ITARS; www.itars.net), European Union Seventh Framework Programme (FP7/2007-13): People, and ITN Marie Curie Actions Programme (2012-16) under Grant Agreement 289923. Installation of the CCN measurements at JOYCE is also supported through ITARS and FZJ and carried out under the coordination of Dr. Thomas Mentel and Dr. Xinxin Li. The AERONET observations are supported through ACTRIS-the research leading to these results has received funding from the European Union Seventh Framework Programme (FP7/2007-13) under Grant Agreement 262254.

The authors especially acknowledge the JOYCEdedicated work of Rainer Haseneder-Lind (University of Cologne), who is responsible for instrument technical maintenance and who makes the continuous operations possible in the first place. We also thank Helga London and Michael Decker (FZJ, IEK-8) for providing support in making JOYCE data available on a near-real-time basis. The HATPRO data shown in the analysis for 25 April 2013 was deployed at JOYCE from April to May 2013 by the University of Hamburg, Germany (Prof. Felix Ament).

\section{REFERENCES}

Albrecht, B. A., 1989: Aerosols, cloud microphysics, and fractional cloudiness. Science, 245, 1227-1230, doi:10.1126/science.245.4923.1227.

Barrett, A. I., R. J. Hogan, and E. J. O'Connor, 2009: Evaluating forecasts of the evolution of the cloudy boundary layer using diurnal composites of radar and lidar observations. Geophys. Res. Lett., 36, L17811, doi:10.1029/2009GL038919.

Berry, E. X., and R. L. Reinhardt, 1974: An analysis of cloud drop growth by collection: Part I. Double distributions. J. Atmos. Sci., 31, 1814-1824, doi:10.1175/15200469(1974)031<1814:AAOCDG>2.0.CO;2.

Betts, A. K., 2007: Coupling of water vapor convergence, clouds, precipitation, and land-surface processes. J. Geophys. Res., 112, D10108, doi:10.1029/2006JD008191.

Bowen, E. G., 1950: The formation of rain by coalescence. Aust. J. Sci. Res., 3A, 193-213.

Brenguier, J.-L., F. Burnet, and O. Geoffroy, 2011: Cloud optical thickness and liquid water path-Does the $\mathrm{k}$ coefficient vary with droplet concentration? Atmos. Chem. Phys., 11, 9771-9786, doi:10.5194 /acp-11-9771-2011.

Crewell, S., and U. Löhnert, 2007: Accuracy of boundary layer temperature profiles retrieved with multifrequency, multi-angle microwave radiometry. IEEE Trans. Geosci. Remote Sens., 45, 2195-2201, doi:10.1109/TGRS.2006.888434.

Dai, A., J. Wang, R. H. Ware, and T. Van Hove, 2002: Diurnal variation in water vapor over North America and its implications for sampling errors in radiosonde humidity. J. Geophys. Res., 107 (D10), doi:10.1029/2001JD000642.

Ebell, K., E. Orlandi, A. Hünerbein, U. Löhnert, and S. Crewell, 2013: Combining ground-based with satellite-based measurements in the atmospheric state retrieval: Assessment of the information content. J. Geophys. Res. Atmos., 118, 6940-6956, doi:10.1002 /jgrd.50548.

Heese, B., H. Flentje, D. Althausen, A. Ansmann, and S. Frey, 2010: Ceilometer lidar comparison: Backscatter coefficient retrieval and signal-to-noise ratio determination. Atmos. Meas. Tech., 3, 1763-1770, doi:10.5194/amt-3-1763-2010. 
Hogan, R. J., M. P. Mittermaier, and A. J. Illingworth, 2006: The retrieval of ice water content from radar reflectivity factor and temperature and its use in the evaluation of a mesoscale model. J. Appl. Meteor. Climatol., 45, 301-317, doi:10.1175/JAM2340.1.

Holben, B. N., and Coauthors, 1998: AERONET-A federated instrument network and data archive for aerosol characterization. Remote Sens. Environ., 66, 1-16, doi:10.1016/S0034-4257(98)00031-5.

Illingworth, A. J., and Coauthors, 2007: Cloudnet: Continuous evaluation of cloud profiles in seven operational models using ground-based observations. Bull. Amer. Meteor. Soc., 88, 883-898, doi:10.1175 /BAMS-88-6-883.

Jiang, H., and G. Feingold, 2006: Effect of aerosol on warm convective clouds: Aerosol-cloud-surface flux feedbacks in a new coupled large eddy model. J. Geophys. Res., 111, D01202, doi:10.1029/2005JD006138.

Karstens, U., C. Simmer, and E. Ruprecht, 1994: Remote sensing of cloud liquid water. Meteor. Atmos. Phys., 54, 157-171, doi:10.1007/BF01030057.

Khairoutdinov, M., and D. Randall, 2006: High-resolution simulation of shallow-to-deep convection transition over land. J. Atmos. Sci., 63, 3421-3436, doi:10.1175/JAS3810.1.

Knuteson, R. O., and Coauthors, 2004a: Atmospheric Emitted Radiance Interferometer (AERI). Part I: Instrument design. J. Atmos. Oceanic Technol., 21, 1763-1776, doi:10.1175/JTECH-1662.1.

— Radiance Interferometer (AERI). Part II: Instrument performance. J. Atmos. Oceanic Technol., 21, 1777-1789, doi:10.1175/JTECH-1663.1.

Kollias, P., E. E. Clothiaux, M. A. Miller, E. P. Luke, K. L. Johnson, K. P. Moran, K. B. Widener, and B. A. Albrecht, 2007: The Atmospheric Radiation Measurement Program cloud profiling radars: Secondgeneration sampling strategies, processing, and cloud data products. J. Atmos. Oceanic Technol., 24, 1199-1214, doi:10.1175/JTECH2033.1.

— , J. Rémillard, E. Luke, and W. Szyrmer, 2011a: Cloud radar Doppler spectra in drizzling stratiform clouds: 1 . Forward modeling and remote sensing applications. J. Geophys. Res., 116, D13201, doi:10.1029/2010JD015237.

—, W. Szyrmer, J. Rémillard, and E. Luke, 2011b: Cloud radar Doppler spectra in drizzling stratiform clouds: 2. Observations and microphysical modeling of drizzle evolution. J. Geophys. Res., 116, D13203, doi:10.1029/2010JD015238.

Korolev, A., 2007: Limitations of the WegenerBergeron-Findeisen mechanism in the evolution of mixed-phase clouds. J. Atmos. Sci., 64, 3372-3375, doi:10.1175/JAS4035.1.
Kottek, M., J. Grieser, C. Beck, B. Rudolf, and F. Rubel, 2006: World map of the Köppen-Geiger climate classification updated. Meteor. Z., 15, 259-263, doi:10.1127/0941-2948/2006/0130.

Löffler-Mang, M., and J. Joss, 2000: An optical disdrometer for measuring size and velocity of hydrometeors. J. Atmos. Oceanic Technol., 17, 130-139, doi:10.1175/1520 -0426(2000)017<0130:AODFMS>2.0.CO;2.

Lohmann, U., and J. Feichter, 2005: Global indirect aerosol effects: A review. Atmos. Chem. Phys., 5, 715-737, doi:10.5194/acp-5-715-2005.

Löhnert, U., and S. Crewell, 2003: Accuracy of cloud liquid water path from ground-based microwave radiometry 1 . Dependency on cloud model statistics. Radio Sci., 38, 8041, doi:10.1029/2002RS002654.

_ - and O. Maier, 2012: Operational profiling of temperature using ground-based microwave radiometry at Payerne: Prospects and challenges. Atmos. Meas. Tech., 5, 1121-1134, doi:10.5194/amt-5-1121-2012.

—, U., S. Crewell, O. Krasnov, E. O’Connor, and H. Russchenberg, 2008: Advances in continuously profiling the thermodynamic state of the boundary layer: Integration of measurements and methods. J. Atmos. Oceanic Technol., 25, 1251-1266, doi:10.1175/2007JTECHA961.1.

— , D. D. Turner, and S. Crewell, 2009: Groundbased temperature and humidity profiling using spectral infrared and microwave observations. Part I: Simulated retrieval performance in clear-sky conditions. J. Appl. Meteor. Climatol., 48, 1017-1032, doi:10.1175/2008JAMC2060.1.

Lohou, F., and E. G. Patton, 2014: Surface energy balance and buoyancy response to shallow cumulus shading. $J$. Atmos. Sci., 71, 665-682, doi:10.1175/JAS-D-13-0145.1.

Long, C. N., J. M. Sabburg, J. Calbó, and D. Pagès, 2006: Retrieving cloud characteristics from ground-based daytime color all-sky images. J. Atmos. Oceanic Technol., 23, 633-652, doi:10.1175/JTECH1875.1.

Mann, J. A. L., J. C. Chiu, R. J. Hogan, E. J. O'Connor, T. S. L'Ecuyer, T. H. M. Stein, and A. Jefferson, 2014: Aerosol impacts on drizzle properties in warm clouds from ARM Mobile Facility maritime and continental deployments. J. Geophys. Res. Atmos., 119, 4136-4148, doi:10.1002/2013JD021339.

Mather, J. H., and J. W. Voyles, 2013: The ARM Climate Research Facility: A review of structure and capabilities. Bull. Amer. Meteor. Soc., 94, 377-392, doi:10.1175/BAMS-D-11-00218.1.

Melchionna, S., M. Bauer, and G. Peters, 2008: A new algorithm for the extraction of cloud parameters using multipeak analysis of cloud radar data-First application and preliminary results. Meteor. Z., 17, 613-620, doi:10.1127/0941-2948/2008/0322. 
Münkel, C., N. Eresmaa, J. Räsänen, and A. Karppinen, 2007: Retrieval of mixing height and dust concentration with lidar ceilometer. Bound.-Layer Meteor., 124, 117-128, doi:10.1007/s10546-006-9103-3.

Neggers, R. A. J., A. P. Siebesma, and T. Heus, 2012: Continuous single-column model evaluation at a permanent meteorological supersite. Bull. Amer. Meteor. Soc., 93, 1389-1400, doi:10.1175/BAMS-D-11-00162.1.

O'Connor, E. J., R. J. Hogan, and A. J. Illingworth, 2005: Retrieving stratocumulus drizzle parameters using Doppler radar and lidar. J. Appl. Meteor., 44, 14-27, doi:10.1175/JAM-2181.1.

Pawlowska, H., J. L. Brenguier and F. Burnet, F., 2000: Microphysical properties of stratocumulus clouds. Atmos. Res., 55, 15-33, doi:10.1016 /S0169-8095(00)00054-5.

Pearson, G., F. Davies, and C. Collier, 2009: An analysis of the performance of the UFAM pulsed Doppler lidar for observing the boundary layer. J. Atmos. Oceanic Technol., 26, 240-250, doi:10.1175/2008JTECHA1128.1.

Peters, G., B. Fischer, and T. Andersson, 2002: Rain observations with a vertically looking Micro Rain Radar (MRR). Boreal Environ. Res., 7, 353-362.

Quaas, J., and Coauthors, 2009: Aerosol indirect effects-General circulation model intercomparison and evaluation with satellite data. Atmos. Chem. Phys., 9, 8697-8717, doi:10.5194/acp-9-8697-2009.

Rodgers, C. D., 2000: Information aspects. Inverse Methods for Atmospheric Sounding: Theory and Practice, F. W. Taylor, Ed., Series on Atmospheric, Oceanic and Planetary Physics, Vol. 2, World Scientific, 13-41.

Rose, T., S. Crewell, U. Löhnert, and C. Simmer, 2005: A network suitable microwave radiometer for operational monitoring of the cloudy atmosphere. Atmos. Res., 75, 183-200, doi:10.1016/j.atmosres.2004.12.005.

Schween, J. H., S. Crewell, and U. Löhnert, 2011: Horizontal-humidity gradient from one single-scanning microwave radiometer. IEEE Geosci. Remote Sens. Lett., 8, 336-340, doi:10.1109/LGRS.2010.2072981.

—, A. Hirsikko, U. Löhnert, and S. Crewell, 2014: Mixing layer height retrieval with ceilometer and Doppler lidar: From case studies to long-term assessment. Atmos. Meas. Tech. Discuss., 7, 4275-4319, doi:10.5194/amtd-7-4275-2014.

Shrestha, P., M. Sulis, M. Masbou, S. Kollet, and C. Simmer, 2014: A scale-consistent terrestrial systems modeling platform based on COSMO, CLM, and ParFlow. Mon. Wea. Rev., 142, 3466-3483, doi:10.1175 /MWR-D-14-00029.1.
Small, J. D., and P. Y. Chuang, 2008: New observations of precipitation initiation in warm cumulus clouds. J. Atmos. Sci., 65, 2972-2982, doi:10.1175/2008JAS2600.1.

- , — , and H. H. Jonsson, 2013: Microphysical imprint of entrainment in warm cumulus. Tellus, 65B, 19922, doi:10.3402/tellusb.v65i0.19922.

Stevens, B., and S. Bony, 2013: What are climate models missing? Science, 340, 1053-1054, doi:10.1126/ science. 1237554.

Turner, D. D., and U. Löhnert, 2014: Information content and uncertainties in thermodynamic profiles and liquid cloud properties retrieved from the groundbased Atmospheric Emitted Radiance Interferometer (AERI). J. Appl. Meteor. Climatol., 53, 752-771, doi:10.1175/JAMC-D-13-0126.1.

— , and Coauthors, 2007: Thin liquid water clouds: Their importance and our challenge. Bull. Amer. Meteor. Soc., 88, 177-190, doi:10.1175/BAMS-88-2-177.

Vereecken, H., S. Kollet, and C. Simmer, 2010: Patterns in soil-vegetation-atmosphere systems: Monitoring, modeling, and data assimilation. Vadose Zone J., 9, 821-827, doi:10.2136/vzj2010.0122.

Walser, A., D. Lüthi, and C. Schär, 2004: Predictability of precipitation in a cloud-resolving model. Mon. Wea. Rev., 132, 560-577, doi:10.1175/15200493(2004)132<0560:POPIAC>2.0.CO;2.

Weitkamp, C., 2005: Lidar: Range-Resolved Optical Remote Sensing of the Atmosphere. Springer Series in Optical Sciences, Vol. 102, Springer, 460 pp.

Wood, R., 2012: Stratocumulus clouds. Mon. Wea. Rev., 140, 2373-2423, doi:10.1175/MWR-D-11-00121.1.

—, T. L. Kubar, and D. L. Hartmann, 2009: Understanding the importance of microphysics and macrophysics for warm rain in marine low clouds. Part II: Heuristic models of rain formation. J. Atmos. Sci., 66, 2973-2990, doi:10.1175/2009JAS3072.1.

Xu, K.-M., and Coauthors, 2005: Modeling springtime shallow frontal clouds with cloud-resolving and single-column models. J. Geophys. Res., 110, D15S04, doi:10.1029/2004JD005153.

Zacharias, S., M. Reyers, J. G. Pinto, J. H. Schween, S. Crewell, and M. Kerschgens, 2012: Heat and moisture budgets from airborne measurements and high resolution model simulations. Meteor. Atmos. Phys., 117, 47-61, doi:10.1007/s00703-012-0188-6.

Zhang, M. H., and Coauthors, 2005: Comparing clouds and their seasonal variations in 10 atmospheric general circulation models with satellite measurements. J. Geophys. Res., 110, D15S02, doi:10.1029/2004JD005021. 